\title{
РОЗУМНЕ СЛОВО ЯК МЕТАЛЕКСИЧНА ХАРАКТЕРИСТИКА
}

Трифонов Р. А. Розумне слово як металексична характеристика.

У статті на матеріалі українського інтернет-дискурсу розглянуто метамовний коментар розумне слово, який супроводжує конкретні лексеми. Показано його важливість для дискурсивної самопрезентації мовної особистості, а також функції, що полягають у підтриманні бажаної тональності спілкування, створенні оцінного значення, запереченні позиції опонента риторичними аргументами.

Ключові слова: метамова, конотація, оцінка, вербальна самопрезентація, агональна комунікація.

Трифонов Р. А. Умное слово как металексическая характеристика.

В статье на материале украинского интернет-дискурса рассматривается метаязыковой комментарий умное слово, сопровождающий конкретные лексемы. Показывается его важность для дискурсивной самопрезентации языковой личности, а также функции, состоящие в поддержке желаемой тональности общения, создании оценочного значения, опровержении позиции оппонента риторическими аргументами.

Ключевые слова: метаязык, коннотация, оценка, вербальная самопрезентация, агональная коммуникация.

Tryfonov R. A. A Smart Word as a Metalingual Description.

In the article, metalingual comment smart word accompanying certain lexemes is considered on the material of Ukrainian internet discourse. Its importance for discourse selfpresentation of language personality is shown alongside with its functions: maintaining the desired mode of communication, creating the evaluative meaning, disproving the opponent's position with rhetoric arguments.

Key words: metalanguage, connotation, evaluation, verbal self-presentation, agon communication.

Розумова діяльність індивіда, відповідні характеристики людини та пов'язаних із іiі життям реалій широко й різноманітно відображуються в мові. Цей фрагмент мовної картини світу, центральною когнітивною структурою в якому є концепт РОЗУМ, узагальнено досліджений у працях Л. Ніжегородцевої-Кириченко, Т. Бичкової, В. Калько, Т. Прудникової, В. Тугаревої на матеріалі прецедентних висловів, а також лексико-фразеологічних підсистем різних мов $[7 ; 2 ; 3 ; 10 ; 13]$. Різноманітність метафоричних репрезентацій зазначеного концепту проілюстрована студіями М. Піменової [8], Н. Сергєєвої [11], О. Купченко [4]. В останній із перелічених праць матеріалом стали агіографічні тексти; 3 цим (C) Р. А. Трифонов, 2012. 
дослідженням перегукується робота Н. Мех, присвячена концепту РОЗУМ у Святому Письмі [5].

Цілком логічно, що концепт, настільки важливий для розуміння образу людини в мові, вивчений нині доволі докладно, хоч i 3 відчутним ухилом у метафоризацію (прикметно, що саме метафорам присвячена основна частина тексту, який передбачає комплексний опис найсуттєвішого в концепті, - статті у виданні «Антология концептов» [11]). Водночас лишаються недостатньо дослідженими певні важливі проблеми, зокрема ті, що пов'язані з залученням репрезентантів концепту до метатекстового й метамовного рівня висловлювань. Тут варто відзначити працю О. Прокубовського, який проаналізував мовні одиниці, що категоризують інтелектуальні здібності людини, в аспекті проблеми розуміння. У зв'язку з цим дослідник вийшов на проблему метаоцінок, пов'язаних із розумінням / нерозумінням мовлення, і зробив низку вартісних спостережень щодо ix вираження [9]. Науковець здійснив роботу 3 одиницями метамовного типу (на матеріалі словосполучень, що містять слово смысл), а також приділив чимало уваги метатекстовим явищам (як вербалізується те, чи зрозумілим є сказане). Рухаючись у схожому напрямі, в цій статті розгляну дещо інакші випадки, у яких інтелектуальний складник мовленого есплікується прямо - через метаозначення розумне слово, при цьому йтиметься про акцент не так на простому розумінні, як на порозумінні в комунікативному процесі.

Отже, мета цієї статті - з'ясувати прагматичне навантаження кваліфікативного словосполучення розумне слово в реальній комунікації. Дослідження виконане на матеріалі інтернет-дискурсу, в усіх цитатах 3 інтернет-сторінок зберігаю особливості написання оригіналу, навіть якщо маємо відступи від норм орфографії та пунктуації.

Слова розум, розумний як ядерні репрезентанти концепту мають виразне оцінне функціональне навантаження, що в прямому значенні стосується людини, а через метонімічні перенесення поширюється на інші об'єкти, одним із яких і є слово. Аксіологічна функція названих мовних одиниць настільки виразна, що лінгвісти слушно вважають їх основними носіями оцінки окремого типу - інтелектуальної. Н. Арутюнова розглядає інтелектуальну оцінку в підсистемі часткових оцінок як один із двох різновидів психологічної (поряд із емоційною) [1, с. 198]. 
Якщо проаналізувати контексти вживання словосполучення розумне слово в сучасному мовленні, то стає помітною закономірність. Носієм позитивної інтелектуальної оцінки «в чистому вигляді» ця сполука є тоді, коли лексема слово в ній уживається в узагальненому значенні 'щось сказане', 'мовлення'. Наприклад: «Читання книжок це запорука успіху в розвитку дитини. Якщьо дитина полюбить книгу вам дуже пощастить. Скажу відверто, іноді ми, дорослі люди, чуємо від наших дорослих дітей високе, розумне слово. I цуе тільки від того, щзо книга вчить думати, розуміти реалії життя» [http://life.pravda.com.ua]. Синонімами лексеми слово тут можуть бути вислів, фраза [див. 6, с. 115, 283], а також судження, твердження, міркування; іiі референція в наведеному контексті охоплює не мовні одиниці, а мовленнєві акти. Такі випадки оцінного слововживання мають системний характер, вони досить поширені і в класичній українській літературі, i в сучасних дискурсах, включно 3 досліджуваною в цій статті інтернет-комунікацією; вони свідчать про концептуалізацію, мають метатекстову природу, але не метамовну.

Однак часто лексема слово в сполуці розумне слово відсилає до конкретного вербального знака, репрезентованого тут же, в контексті. Тоді ми виходимо на метамовний (металексичний) рівень, а прагматика словосполучення набуває зовсім інакшого характеру: воно стає засобом дискурсивного позиціонування мовця, який висловлює ставлення до мови й до світу. 3 огляду на мовну свідомість, стилістичні пріоритети, комунікативні настанови та фонові знання, словосполучення розумне слово виявляє широкий оцінний діапазон.

Вельми поширеними є випадки, у яких розумне слово - це метамовний автокоментар до вживання певної лексеми в мовленні. Цей коментар може бути оцінно нейтральним: "Для активації $я$ поділила дітей на команди. За правильні відповіді давала “Енчантікс" (жетони у вигляді сердечок). Для тих, хто не знає, щзо означає ие слово, розкажу - це таке розумне слово $з$ мультика» [http://megasite.in.ua]. Тут розумне слово - це визначення для ймовірного (з погляду мовця) агноніма. Лексема відсилає до прецедентного феномену, і якщо він відсутній у когнітивній базі реципієнта, це стане причиною агнонімії. Введення метамовного засобу тут зумовлене суто комунікативною потребою розуміння, адекватної передачі інформації на денотативному рівні. Водночас прикметник розумне дещо пожвавлює інформативний коментар, надає 
йому відтінку іронії чи принаймні якоїсь важко вловлюваної конотації, за якою стоїть людина, а не чиста інформація. І от із такими відтінками частіше мають справу мовець і реципієнт у випадках уживання досліджуваного словосполучення.

Здебільшого визначення розумне слово як автокоментар, лишаючись комунікативно навантаженим, сигналізує про конотативні виміри лексичних одиниць: «Популяризащії дуже зручного міфу про приреченість любові сприяла книга франиузького письменника Фредеріка Бегбедера “Любов живе три роки”, а також дослідження мексиканки Хеорхіни Монтемайор Флорес, в результаті яких вона вивела схожу цифрру, після чого багато молодих людей отримали карт-бланш (яке розумне слово) на розрив стосунків» [http://pereval.mobi]; "Думаю, ні для кого не новина, щзо я належу до групи людей “люблю повеселиться, особенно пожрать”. I звісно, мене завжди цікавило, щзо б такого смачного/незвичайного/тощзо можна знайти у нас. [...] Спонукана вимушеною дієтою, а також бажанням урізноманітнити свій раціон (о, як розумне слово), я почала шукати, чим у нас можна розжитися, так би мовити, вітчизняним» [http://lana-svitankova.livejournal.com]. Тут і в подібних ситуаціях зауваження щодо слова детерміновані мовною свідомістю, зокрема стилістичними пріоритетами та уявленнями про стилістичну маркованість. Вставна конструкція тісно пов'язана 3 дискурсивною самопрезентацією дописувачів як мовних особистостей: так пом'якшується наявний у їхньому сприйнятті стильовий дисонанс у межах мовленнєвого фрагмента i реалізується прагматичний намір зберегти оптимальне комунікативне порозуміння 3 реципієнтом, не вийти за межі невимушеного спілкування. Такі стилістичні й прагматичні особливості споріднюють метамовні коментарі досліджуваного типу 3 рефлексіями щодо пафосу [див. 12]. Пор. також: «Не секрет, щуо ми любимо, коли нас ведуть по життю за руку. Пасивна поведінка вимагає менше витрат енергії, ніж активна, i наш організм економить сили. Така система закладається ще $з$ народження: спочатку ми залежали від батьків, потім покладалися на вчителів у школі, потім був університет або інститут з викладачами, а надалі - робота $i$ начальник. Як бачите, патерналістська (ось це розумне слово!) Система пронизує багато сфер нашого життя, тому немає нічого дивного в тому, що люди бояться відповідальності» [http://stattja.pp.ua]. Маємо своєрідну 
дилему: з одного боку, мовець, аналізуючи психологічні та соціальні феномени, повинен висловлюватись аналітично й фахово, демонструвати власну компетенцію; 3 другого - мусить дбати про належний комунікативний контакт із реципієнтом. Пошук балансу між тим і другим зумовлює автокоментарі: «Війни зараз все ж переважно ведуться паперові чи, швидше, медійні - за вплив на душі. Це називається розумним словом інформачійний простір» [http://artvertep.dp.ua]; «Ситуація, в якій опинилась Украӥна, називається розумним словом “иугцванг” - це коли будь-яка дія лише nогіриує ситуащію» [http://durdom.in.ua]. В останньому прикладі метамовний вимір не вичерпується констатацією «розумності» слова, мовець розтлумачує його семантику для максимального розуміння i водночас наділяє лексему 3 погляду власного ідіолекту статусом маркованої, чим непрямо характеризує себе як мовну особистість.

Той образ мовця, який постає внаслідок уживання «розумних слів», може викликати іронічне сприйняття самого суб' єкта мовлення (це самоіронія, яка теж сприяє збереженню належного комунікативного контакту): «Гурмани не дрімають в гонитві за гострими відчуттями, так щзо сучасне виробництво забутих прянощів починає потихеньку відроджуватися. Здається, ие називається розумним словом - ребрендинг. :)» [http://stasboreyko.trips-in.ru]. Водночас завдяки розумному слову вводиться додаткова експресія, яка поширюється на попереднє речення й дозволяє мовцеві, очевидно, комунікативно привабливіше оформити свою констатацію; також розумне слово дозволяє «згорнути» пропозитивну номінатему «сучасне виробництво [...] починає потихеньку відроджуватися» до однослівного елементного позначення, що, без сумніву, увиразнює сказане. У наступному прикладі самоіронія органічно доповнює легкий стиль повідомлення 3 поєднанням інформативності, емоційності й комічності: «Дорога до місия призначення виявилася веселою, багатою на події $i$ навіть пізнавальною (сам не знаю чому пізнавальною, просто хтів похвалитися шо вивчив нове розумне слово). Всі шість годин тридиять три хвилини і сорок дві секунди (приблизно) ми тільки й те робили шо гнали, але не самогон, а шутки шутки $i$ ше раз жарти» [http://optom.at.ua]. Об' єктом іронії в наведеному уривку стає, крім самого суб'єкта мовлення, ще й мовне кліше, адже ряд означень, що супроводжують слово дорога, $є$ стандартним, i мовець, як мені 
здається, іронізує не лише 3 себе, а й загалом 3 автоматизму відтворення цього ряду.

Однак зазвичай суб'єктом, який вивчив нове розумне слово, виявляється не сам мовець, а Інший або Чужий, також присутній у дискурсі. Дуже поширені зауваження про розумне слово в діалогічній комунікації, в полеміці. Якщо аргументація риторичного опонента видається мовцеві недостатньою, металексичний коментар, спрямований на семантичні особливості ключового слова, стає агональним прийомом. Із діалогу на форумі: «Захід уже пожинає плоди від покоління “гаррі потерів” - згадайте бунти підлітків у Лондоні» - «Тобто ви вважаєте, щуо ті виродки, щзо громили минулого року Лондон начиталися “Гаррі Поттера”? Насмішили» - «Йдеться лише про хронологію та сочіологію: “Гаррі Потер” продавався мільйонами, одна за одною виходили екранізації саме тоді, коли ичі “виродки” ходили у садки та до школи» - "“соиіологія” - це наука, а не просто гарне "розумне” слово. Можете на якісь соціологічні дослідження послатися? На взір: “Гаррі Поттер” $i$ розвиток nідліткового вандалізму”» [http://litakcent.com]. Або: “Чесно кажучи, я б по-інакшому, мабуть, сприймала роман п. Матіос, як він мені не видавався б найконкретнішою сублімачією якихось переживань, дійсно аналогічних невиправданому і легковажному потягові, от-як дитячий потяг головної героїні до цукерок. Я не розумію, це поважна проблема? Просто на мою ментальність иче якось не лягає» - «Мдя-аa, от що буває, коли людина почує десь розумне слово і починає го тулити де попало. То щзось людині на ментальність не лягає, то віршувати художню прозу вона хоче...» [www.ukrcenter.com]. Тут риторичний конфлікт загострюється розгортанням метамовного коментарю в бік оцінки мовної компетенції, а отже, освіченості опонента. Наступний щабель інтенсифікації дискурсивного конфлікту навішування ярликів, використання інвективної лексики для номінації опонента, спричинене також уживанням розумного слова: «колабораціоністи прийшли до влади, україні торба»- «Довбодятел, вичитав розумне слово, зрозумів його на 20\% [...] $i$ заявив: “колабораціоністи прийшли до влади!!!”. Але якщз ти переконаний в цьвому на 100\%, тоді назви речі свойми іменами (на хлопський розум, кого ти вважаєш колабораціоністом, кого загарбником а також наведи факти колаборащіонізму). Тоді, можливо, я заберу свої слова назад. А зараз ти довбодятел!!!» [http://news.if.ua]. 
Оскільки політика є концептосферою, у якій використовуються розумні слова, і водночас предметом суджень пересічного мовця, котрий оперує повсякденною логікою й відповідною лексикою, коментар розумне слово поширений у політичному та навколополітичному дискурсах. Вище ми бачили приклад навколополітичної полеміки на форумі - прямий діалог. Крім того, другим учасником діалогу може ставати політик, і тоді виходить діалог-метатекст: «Ахтунг! Щойно, 10 листопада 2008 року, о 15-00, y новинах по Украӥнському Радіо, оголосили заяву Президента Ющенка. Президент Ющенко з усією притаманною йому рішучістю та сміливістю заявив, щуо влада (!) повинна (!!) зробити ВСЕ МОЖЛИВЕ (!!!) для того, щуоб мінімізувати (яке розумне слово!!!!) негативні наслідки світової фінансової кризи в Украӥні (!!!!!!!!!!!). Ви розумієте?? Ще раз повторю: влада (не Президент, а саме Влада!) повинна зробити все можливе, шуоб - і так далі. Це ж треба було так довго думати, щзоби аж сьогодні вигадати таку хитромудру стратегію та заодно і тактику. Криза всього лише кілька місящів, як розпочалася, а Президент уже - хоп! - $і$ має готовий рецепт, як ї̈ побороти! Ну хіба не ласточка? Хіба не золотко наш Президент?» [http://koka.pp.net.ua]. Коментар розумне слово до мовлення політика позначений крайнім ступенем іронії (як і весь текст), це імпліцитна вказівка на те, що розумне слово не матиме належного ефекту, $є$ недоречним і неадекватним, тобто втрачає зв'язок із дійсністю (саме цю імплікацію мовці прагнуть усунути в автокоментарях, але охоче вводять у коментарях до чужих слів). Подібний засіб риторичної боротьби може ефектно застосовувати у своєму мовленні й сам політик - на адресу опонента. Народний депутат Кирило Куликов: «Світовий банк кілька років тому виділив громі на соціальні програми, про які Тігіпко весь час говорить. Так треба ж їх використовувати, але цього не відбувається. Програма дозволить порахувати, у кого в Україні які пільги, компенсацї, кому $і$ скільки сплачується. Це розумне слово, яке вивчив Сергій Леонідович, “інвентаризація пільг”. Як завжди було закуплено “залізо”, щось в нього було “забито”, але иъього року ия система знову не буде працювати...» [http://ia-prometei.org.ua].

Оскільки розумне слово в мовленні політиків, із точки зору критично налаштованих громадян, не має зв'язку з дійсністю, воно може репрезентуватися як евфемізм, як засіб маскування (ㄱ Р. А. Трифонов, 2012. 
непривабливих намірів і дій політиків: «Ще вчора вони тузами клялися своїм лідерам у вірності й відданості. А нині ведуть закулісні переговори з посередниками, аби “виторгувати” собі хоч якесь кріселко у новій владі. А щуоб ніхто не здогадався, щзо насправді відбувається, прикрилися розумним словом “коаліціада". Мовляв, йде формування нової коалічії. Так тепер цее називається в Україні. I в той час, коли народ завмирає перед телеекранами в очікуванні повідомлень із Києва, у столиці тривають банальні "торги”: хто погодиться зрадити своӥх колишніх і продатися новим господарям» [www.vybir-lviv.com]. Дискурсивне позиціонування мовця полягає не просто в опонуванні політикам як чужим, а в називанні речей «своїми іменами». Тоді мовець постає, на відміну від політиків, як носій «справжнього», не викривленого дискурсу.

Ще один прийом вербальної дискредитації політиків, пов'язаний із досліджуваним метамовним засобом, - це приписування певній лексемі в їхній картині світу конотативної характеристики розумне слово: «Мене взагалі завжди дуже дивувало, чому ие депутати пишуть законопроекти спільно. У них, щуо у кожного окремо мізків бракує? Чи спрацьовує стадний інстинкт? А може $з$ міркувань симбіозу - один вміє читати, другий писати, третій знає розумне слово “законопроект", четвертий - має на власному айпад $i$ фотографію, як правильно оформлювати...» [http://infoporn.org.ua]. Фрагмент про знання розумного слова “законопроект” - це іронічний складник стратегії дискредитації опонента через пресупозиції («не всі депутати знають слово“законопроект"»; «для депутатів це слово $є$ розумним, а не повсякденно-звичним»). Маркована лексема $\epsilon$ частиною фахового словника депутата, тобто останній має нею оперувати у своїй повсякденній діяльності, а приписування такому слову спеціальної ознаки «розумності» має знижувати образ політика, чия мовна картина світу подається як неадекватна статусу.

Водночас так само засобом дискредитації опонентів - у цитованому нижче прикладі вже не політиків - може бути й «надмірне» володіння розумними словами, яке теж відчужує: «Брюх, Панченко, Моренець - філологи, $і$ вони мені не подобаються, ібо уособлюють той негатив, про який я писав... Історія $i$ теорія літератури - добре, я нічого не кажу. I все одно, ви намагаєтесь придумати те, чого немає, і назвати якийсь твір розумним словом, придумати йому класифікачію, намагатись визначити, які 
подіï/речі/світогляди вплинули на автора» [http://bo-netua.cc.colocall.com]. Отже, і володіння розумним словом, і неволодіння ним можуть оцінюватися негативно залежно від різноманітних настанов суб'єкта. Таким чином, у подібних випадках інтелектуальна оцінка відіграє допоміжну роль і стає амбівалентною («розумне слово добре» $\mathrm{i}$ «розумне слово - погано» співіснують у реальних мовленнєвих практиках), а домінує оцінка нормативна й утилітарна, все залежить від того, що $\epsilon$ нормою i приносить результат. Схематично це має такий вигляд: «розумне слово - добре» VS «некомпетентність»; але «розумне слово - погано» VS «простота», «зрозумілість».

Коментар про розумне слово, як бачимо, часто супроводжується вказівкою на суб'єкта. Як уже сказано, цим суб'єктом може бути Інший або Чужий. У випадку, коли йдеться про Іншого, різкого протиставлення немає, в номінативному акті відображується лише гетерономінативність: "Почалася ланцюгова реакція подорожчання всього, щчо годиться в їжу. У народному розумінні цุе $i \epsilon$ те, щзо державні статистики називають розумним словом “інфляція” (з газети «Товариш») [www.spu.in.ua]. 3 одного боку, автор не протиставляє себе суб'єктам номінації, названим державні статистики, 3 другого - він цілком очевидно хоче перебувати в одному дискурсі не 3 ними, а зі своїм читачем, який використовує простіші мовні засоби. А от ситуація з Чужим у ролі номінативного суб'єкта вербалізується як різке протистояння, це можна було простежити в низці попередніх прикладів. Переважає в подібних випадках заперечення доречності вживання слова в тому чи іншому контексті. Арсеній Яценюк до представників влади: «Зараз всі реформи звелися до наступного: будемо піднімати на все иіни, будемо скорочувати всі бюджетні видатки, будемо займатися так званою монетизацією пільг, розпродамо все державне майно. Так ие не реформи. Моя порада Януковичу, Азарову і всім іншим: хлопці, ви не прикривайтеся цим розумним словом “реформи”. Ви скажіть чітко, щุо ви хочете зробити в краӥні. Якщьо ви не знаєте, щзо робити, то так вийдіть $i$ скажіть, що ми не знаємо, щзо робить» [www.pravda.com.ua]. Мовець не заперечує слово реформи як елемент лексичної системи і навіть мови політики, він лише вважає хибним певне його вживання (пор. вище зауваження про слова колабораціоністи, ментальність тощо). А от крайньою формою (ㄱ Р. А. Трифонов, 2012. 
дискурсивного опонування Чужому є заперечення вербального знака в мовній картині світу взагалі - як такого, що належить до хибного світобачення: «Притримуюсь думки, що такого поняття як сексуальне збочення не існує, його люди видумали щоб ображати розумним словом те, щьо їм самим не подобається. Надаю перевагу таким термінам як “хвороба" $i$ “відхилення" у випадках 3 педофілами, маньяками, іншими людьми які щзось чинять ПРОТИ ВОЛІ “партнера”. А от гомосексуали, які добровільно один з одним заводять стосунки - ие їхня справа...» [http://tereveni.org]. Тут маємо знов-таки нормативну оцінку, а сполука розумне слово набуває виразно негативного оцінного забарвлення (ображати, не подобається).

Отже, словосполучення розумне слово, коли воно стосується конкретних лексичних одиниць i $\epsilon$ маркером метамовного, а не метатекстового рівня, має складну й неоднозначну прагматику. За його допомогою, коментуючи власне слововживання, мовець декларує власні ідіолектні настанови, стилістичні пріоритети i цим здійснює самопрезентацію в дискурсі та запобігає комунікативному відчуженню 3 боку реципієнта. Якщо ж коментар спрямований на чуже мовлення, то вислів, навпаки, стає потужним засобом відчуження і позиціонування себе в «правильному» дискурсі на противагу «неправильному» дискурсу опонента. У ході реалізації таких прагматичних настанов відбуваються різноманітні оцінні трансформації: початково властива означенню розумне інтелектуальна оцінка редукується і стає амбівалентною, частіше негативною; на передній план виходять нормативні та утилітарні оцінки. Як показують дослідження металексичних коментарів 3 оцінним компонентом, їхня прагматика є складною й майже не дослідженою, тож потребує дальших студій.

\section{Література}

1. Арутюнова Н. Д. Язык и мир человека / Н. Д. Арутюнова. - [2-е изд., испр.]. М. : Языки рус. культуры, 1999. - I-XV, 896 с.

2. Бычкова Т. А. Концепт «разум» в русской языковой картине мира / Т. А. Бычкова // Русская и сопоставительная филология: состояние и перспективы : Междунар. науч. конф., посвящ. 200-летию Казан. ун-та (Казань, 4-6 окт. 2004 г.) : труды и материалы. - Казань : Изд-во Казан. ун-та, 2004. - С. 260-261.

3. Калько В. Репрезентація рівня інтелектуального розвитку людини в українських пареміях / Валентина Калько // Наук. вісн. Херсонського держ. ун-ту. Сер. «Лінгвістика». - 2010. - Вип. 10. - С. 187-192. 
4. Купченко Е. А. Метафора «вместилище» в структуре концепта «разум» (на материале агиографической литературы) / Е. А. Купченко // Уч. зап. Таврич. нац. ун-та им. В. И. Вернадского. Сер. «Филология. Соц. коммуникации». - Т. 24 (63), № 1, ч. 1. $-2011 .-$ С. 358-362.

5. Мех Н. О. Концепт розум у Святому Письмі [Електронний ресурс] / Наталія Mex. - Режим доступу : http://www.kulturamovy.org.ua/KM/pdfs/Magazine68-69-11.pdf.

6. Мех Н. О. Лінгвокультурологема ЛОГОС у науковій, релігійній та художній картинах світу : монографія / Наталія Мех. - К., 2011. - 410 с.

7. Ніжегородцева-Кириченко Л. О. Лексико-семантичне поле «нтелектуальна діяльність»: досвід концептуального аналізу (на матеріалі іменників сучасної англійської мови) : автореф. дис. ... канд. філол. наук : спец. 10.02.04 - герм. мови / Л. О. Ніжегородцева-Кириченко. - К., 2000. - 21 с.

8. Пименова М. В. Антропоморфная парадигма признаков в структуре концепта УМ / М. В. Пименова // Вестн. Воронеж. гос. ун-та. Сер. «Лингвистика и межкульт. коммуникация». - 2004. - № 2. - С. 32-35.

9. Прокубовский А. А. Категоризация интеллектуальных способностей человека и лексические маркёры понимания в русском языке : автореф. дис. ... канд. филол. наук : спец. 10.02.01 - рус. яз. / А. А. Прокубовский. - М., 2009. - 24 с.

10. Прудникова Т. І. ДУША, СЕРЦЕ, РОЗУМ: особливості концептуалізації в українській фразеології / Т. І. Прудникова // Уч. зап. Таврич. нац. ун-та им. В. И. Вернадского. Сер. «Филология. Соц. коммуникации». - Т. 24 (63), № 1, ч. 1. 2011. - C. 295-299.

11. Сергеева Н. М. Ум и разум / Н. М. Сергеева // Антология концептов / под ред. В. И. Карасика, И. А. Стернина. - М. : Гнозис, 2007. - С. 210-223.

12. Трифонов Р. А. Деякі прагматичні особливості вибачень за пафос у блогосфері (на матеріалі слов'янських мов) / Р. А. Трифонов // Мовознавство. - 2011. - № 3. - С. 41-49.

13. Тугарева В. В. Лексико-семантическая представленность концепта «разум» в английском и русском языках (на материале лингвистических тестов) : автореф. дис. ... канд. филол. наук : спец. 10.02.20 - сравн.-ист., типолог. и сопост. языкознание / В. В. Тугарева. - М., 2011. - 23 с. 